\title{
Rehabilitation of patient suffering from myocardial infarction: the importance of physical training
}

\author{
(1D)Emir Becirovic ${ }^{1 *}$ \\ (D)Ammar Brkic', \\ DEsad Brkic', \\ (DTarik Brkic', \\ (D)Ermina Mujanovic ${ }^{2}$, \\ (D)Amir Becirovic ${ }^{2}$, \\ Demir Hadzic ${ }^{2}$, \\ (D)Amila Jasarevic', \\ (iD) Majda Skokic', \\ (iD)Esref Becirovic ${ }^{2}$
}

'University Clinical Center Tuzla, Tuzla, Bosnia and Herzegovina

${ }^{2}$ Univerzitet of Tuzla, School of Medicine, Tuzla, Bosnia and Herzegovina

RECEIVED:

October 25, 2018

ACCEPTED:

November 5, 2018

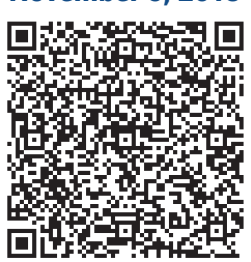

$\square$ Cardiologia Croatica 2018;13(11-12):416.

\begin{abstract}
KEYWORDS: myocardial infarction, exercise training, cardiovascular rehabilitation. CITATION: Cardiol Croat. 2018;13(11-12):416. | https://doi.org/10.15836/ccar2018.416
\end{abstract}

*ADDRESS FOR CORRESPONDENCE: Emir Bećirović, JZU Univerzitetski klinički centar Tuzla, Klinika za interne bolesti, Prof. dr Ibre Pasica, 75000 Tuzla, Bosnia i Herzegovina. / Phone: +387-61-876-152 / E-mail: becirovic.emir@live.com ORCID: Emir Becirovic, https://orcid.org/0000-0002-4134-987X • Ammar Brkic, https://orcid.org/0000-0002-5436-3670 Esad Brkic, https://orcid.org/0000-0002-7784-328X • Tarik Brkic, https://orcid.org/0000-0003-2054-2571

Ermina Mujanovic, https://orcid.org/0000-0001-8154-586X • Amir Becirovic, https://orcid.org/0000-0002-7012-8064 Semir Hadzic, https://orcid.org/0000-0002-3308-8331 • Amila Jasarevic, https://orcid.org/0000-0003-4861-6683 Majda Skokic, https://orcid.org/0000-0001-5913-1863 • Esref Becirovic, https://orcid.org/0000-0003-3759-7878

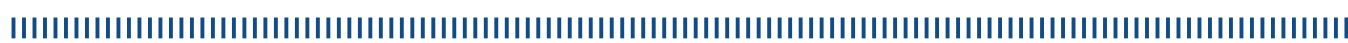

Rehabilitation of patient suffering from myocardial infarction has a goal to recover physical, psychological and social functions up to optimal level. It begins with the first contact with patient and it is conducted continuously till the end of life. Exercise training presents the basic rehabilitation method for cardiovascular patients. When prescribing the exercise training, must be taken care of: life's age, gender, muscle-skeletal system integrity, previous physical activity, myocardial infarction (MI) size, ventricular function and functional heart condition, as well as medicaments that patient uses. Exercise training in order to lead to good effects, it must be isotonic or aerobic type. It includes the workout of large muscle groups which demands increased lung ventilation, increased minute-volume of the heart and small increasement of artery blood pressure. A certain number of studies have shown that exercise training can lead to functional capacity increasement even with patients with significant ventricular function disturbances. Increasement of maximal oxygen body consumption under exercise training influence is the first of all the consequence of periphery mechanisms adaptation (increasement of artery-vein oxygen difference, sympathetic nerve system stabilization with lower levels of heart frequency and blood pressure in calm condition and in effort condition) and it can be archived in situations when improvement of disturbed intrinsic heart frequency is hardly expected. ${ }^{1-3}$

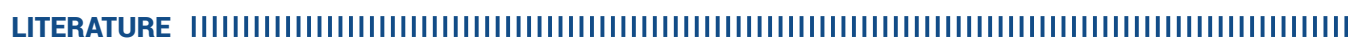

1. Leon AS, Franklin BA, Costa F, Balady GJ, Berra KA, Stewart KJ, et al; American Heart Association; Council on Clinical Cardiology (Subcommittee on Exercise, Cardiac Rehabilitation, and Prevention); Council on Nutrition, Physical Activity, and Metabolism (Subcommittee on Physical Activity); American association of Cardiovascular and Pulmonary Rehabilitation. Cardiac rehabilitation and secondary prevention of coronary heart disease: an American Heart Association scientific statement from the Council on Clinical Cardiology (Subcommittee on Exercise, Cardiac Rehabilitation, and Prevention) and the Council on Nutrition, Physical Activity, and Metabolism (Subcommittee on Physical Activity), in collaboration with the American association of Cardiovascular and Pulmonary Rehabilitation. Circulation. 2005 Jan 25;111(3):369-76. https://doi.org/10.1161/01.CIR.0000151788.08740.5C

2. Stone JA, Arthur HM; Canadian Association of Cardiac Rehabilitation Guidelines Writing Group. Canadian guidelines for cardiac rehabilitation and cardiovascular disease prevention, second edition, 2004: executive summary. Can J Cardiol. 2005 0ct;21 Suppl D:3D-19D. https://www.ncbi.nlm.nih.gov/pubmed/16292364

3. Lavie CJ, Milani RV. Cardiac rehabilitation, exercise training, and psychosocial risk factors. J Am Coll Cardiol. 2006 Jan 3;47(1):212; author reply 212-3. https://doi.org/10.1016/j.jacc.2005.10.002 